\title{
Research on the Cultivation of College Students' Entrepreneurship under the Perspective of Entrepreneurial Economy
}

\author{
C. Jin, Z.G. Ke \\ Jiangxi Science and Technology Normal University \\ Jiangxi, China
}

\begin{abstract}
In the process of the economic development, education first. The 21st century is the era of big development of economy, which needs a large number of high-quality entrepreneurial talents. College students are the most dynamic and the most potential entrepreneurial leadership. Only developing college students' training for entrepreneurship ability, fostering entrepreneurial talents, can we provide solid intelligence support for the development of entrepreneurial economy. Under the perspective of entrepreneurial economy, considering such aspects as individual, family, college and society etc. on the analysis of the connotation of college students entrepreneurial capacity constraints and ability, we put forward the mechanism of college students' entrepreneurial ability with positioning concept of college students' entrepreneurial ability training correctly in our country.
\end{abstract}

Keywords-entrepreneurial economy; college students' entrepreneurial ability; training system; entrepreneurial talent

\section{INTRODUCTION}

Entrepreneurial economy has become the mainstream of contemporary social and economic development. Developing entrepreneurial economy will become the new driving force for the economy to develop sustainably, rapidly and healthily. In the era background of developing entrepreneurial economy in our country, as the main body of entrepreneurial activity, college students' entrepreneurial activity. should be cultivated.

\section{THE CULTIVATION OF ENTREPRENEURIAL ABILITY IS AN INTERNAL DRIVING FORCE}

The entrepreneurial master Larry Farrell once said that the development of entrepreneurial economy is crucial to win the global economic war in the $21^{\text {st }}$ century. [1]Starting a business will inevitably become the main current in the development of the economic society. Many countries including China are starting to develop the entrepreneurial economy and encourage the launch of entrepreneurial activities. The entrepreneurial economy combines knowledge, technology, management and capital with entrepreneurial spirit, which boosts the economy, increases the employment opportunities and thus promotes the social progress. It has become the best development way of a country towards a new economic era.

The development of the entrepreneurial economic society demands a group of high- quality talents. As the high- quality talents, college students will inevitably become the main body of the entrepreneurial economic society. To energetically cultivate college students' entrepreneurial ability is a need for the change of talent demand during the period of social and economic structure adjustment as well as a kind of education form to adapt to the reform in the structure of the entrepreneurial economy. The cultivation of college students' entrepreneurial ability offers a solid intellectual foundation for the development of entrepreneurial economy, enabling college students to carry out the entrepreneurial activity smoothly. Meanwhile, it also promotes the transformation of technology and innovation, improves the quality of the industry and facilitates the highly-developed industry, which is of great significance to the sustainable development of the entrepreneurial economy in China.

\section{The Restrictive FACtOR ANALYSIS OF COLLEGE STUDENTS’ ENTREPRENEURIAL ABILITY}

College students, as a special group, have some advantages in entrepreneurship, such as a higher level of knowledge and stronger ability of independent innovation. But the current situation of their entrepreneurship is not optimistic and their entrepreneurial ability is constrained. The analysis of reasons is as follows:

\section{A. The Entrepreneurial Promotion Is Too Utilitarian}

One of the most common slogans used to encourage college students to carve out in our country is that entrepreneurship motivates the employment. Meanwhile, the government encourages college students to start a business, mainly to reduce the pressure brought out by college students' employment problems. The entrepreneurial orientation with a strong utilitarian color will lead to the narrow understanding of entrepreneurial activity in society, which will ultimately affect the formation of college students' concept of entrepreneurial ability training.

\section{B. The Sense of Entrepreneurial Identity Is Not Strong}

Influenced by the education of traditional culture, Chinese society is inclined to be conservative and keep to the beaten track. For most people, the ideal employment is to be civil servants, work in national enterprises and institutions or find a well-paid occupation. In their mind, entrepreneurship is very tough with a high risk, which is conducted by those students who ignore their proper duties. The maximum resistance quite a few students are faced with when they start a business come from the negative public opinions of all sides. 


\section{College Students Are Short of Venture Capital, the Prerequisite for Entrepreneurship}

Many college students have no money and no credibility, so it is difficult for them to raise capital for launching venture projects. At present, college students' venture capital mainly comes from family or friends, other financing channels being blocked. Due to the limitation of their own funds, colleges and universities find it difficult to take out plenty of special funds to ensure the smooth implementation of college students' entrepreneurial activities. The government has insufficient financing policy and support. Currently, there are some preferential policies in reducing or exempting taxes and providing free services of consulting the policies and information. Although it is regulated in some policies that college students may apply for small loans from the banks when starting a business, actually few students succeed in obtaining the loans, for most of the banks are reluctant to lend to those small- scale and high-risk college students with poor repayment ability.

\section{College Students Are Lacking in Entrepreneurial \\ Confidence}

They also lack the relevant entrepreneurial knowledge and managerial knowledge so they do not know how to deal with the business. Pioneering consciousness as they have, it is still difficult to really start entrepreneurial activity. At the same time, college students' living conditions are so monotonous that they lack the awareness of society and the sense of responsibility and the resistance to frustration are not strong. As a result, they can hardly withstand the impact of starting a business.

\section{E. Universities Lack the Entrepreneurial Education for College Students}

In recent years, having realized the importance of cultivating college students' entrepreneurial ability, universities began to educate college students in entrepreneurship and launch the competitions and training classes related to entrepreneurship on campus, and some universities established business incubators. These measures had some effect in colleges and universities, but they were not so ideal. At present, universities in our country have not formed a complete education system of the entrepreneurial education and guidance. First of all, lack teachers in the entrepreneurial education. Entrepreneurial education training classes are generally taught by ordinary teachers who do not receive any training about entrepreneurship, nor own entrepreneurial experiences and ability of practice. They are simply scripted when teaching, which is difficult to obtain corresponding effects.

\section{The Cultivation Mechanism of College STUDENTS' ENTREPRENEURIAL ABILITY UNDER THE PERSPECTIVE OF ENTREPRENEURIAL ECONOMY}

\section{A. Fully Stimulate College Students' Main Body Consciousness}

The cultivation of college students' entrepreneurial ability need the support of family, school and society, and more stimulation of students' subject consciousness. College students should develop their entrepreneurial ability positively, actively and creatively in order to realize the combination of college students' entrepreneurial ability training and self cultivation. [2]

\section{1) Establish a Strong Sense of Entrepreneurship}

Entrepreneurial economy will become the mainstream of economic development in the 21st century. College students need to be aware of the economic trend, grasp the law of economic development and realize that the ability of self-employment has become one of the important abilities for college students' future development. They ought to change the employment idea and attach importance to entrepreneurial activity, usually paying attention to cultivating their awareness and taking the cultivation of entrepreneurial ability as one of the important tasks in college.

\section{2) Consolidate the Related Knowledge of Self-Employment}

Entrepreneurial ability is the concentrated reflection of college students' comprehensive ability and quality. As the main body of entrepreneurial activity in the entrepreneurial economy, college students should study hard, laying a solid knowledge foundation for self-employment. Entrepreneurial ability includes not only professional knowledge, but also entrepreneurial execution, such as judgment ability, decision-making ability, organization and management ability, operation ability, learning ability and cooperative communication ability and other comprehensive knowledge.

\section{3) Participate in Entrepreneurial Practical Activities}

College students need to actively participate in entrepreneurial practical activities, such as special training on entrepreneurial ability, SYB entrepreneurial training and training of college students' entrepreneurial education projects. In the entrepreneurial practical activities, students can test their entrepreneurial ability level and improve the career consciousness, psychological quality and entrepreneurial execution. Environment permitting, college students can adopt the methods like field trips or internships to understand the enterprise operation process so that they can integrate into the social and economic tide as soon as possible when starting a business.

\section{B. Create a Good Atmosphere for Cultivating College Students' Entrepreneurial Ability}

All sectors of society should create a good atmosphere for entrepreneurial ability training, forming a sense of identity with college students' entrepreneurship, which should be conducted from the following three levels, family, college and society.

\section{1) The Family Level}

Parents should change their ideas, learning the significance of entrepreneurship essentially and realizing that entrepreneurship can not only solve the issue of employment, but it is also an effective way for their children to realize self value through their own efforts. At the same time, parents should respect their children's entrepreneurial choice and put forward constructive suggestions for children's entrepreneurial behavior as far as possible, offering the ideological guidance and financial support to their children's entrepreneurship. 


\section{2) The Colleges and Universities Level}

Colleges and universities are the main position of cultivating college students' entrepreneurial ability. Universities should consciously cultivate students' entrepreneurship, correctly locate students' entrepreneurial value orientation and guide students to consider self-employment as an effective way to serve the society and realize their value of life. At the same time, universities should set up a model of college students' entrepreneurial success and give extensive publicity, putting emphasis on advocating those entrepreneurs who failed repeatedly without being discouraged and ultimately achieved success so as to encourage the frustrated entrepreneurs to start again and thus create a good atmosphere of campus entrepreneurship.

\section{3) The Social Level}

Form a positive, entrepreneurship-encouraging and entrepreneurship-tolerant atmosphere which provides help for entrepreneurs. Therefore, all sectors of society should play a guiding role, strengthen the consensus propaganda and policies related to entrepreneurship and utilize all kinds of media, such as Internet, newspapers and television to propagandize, creating a favorable environment for entrepreneurship to encourage college students to be bold in entrepreneurship, be delightful in entrepreneurship and be skillful in entrepreneurship.

\section{Set Up the Education System of College Students' Entrepreneurial Ability Training}

1) Strengthen the Organization and Leadership to Ensure the Work of College Students' Entrepreneurial Ability Training

Entrepreneurship training is an important part of college students' quality education. College students' entrepreneurial ability training work demands the implementation of "the leadership project" by the party and government leadership and the establishment of the leading team concerning the entrepreneurial ability training work. The school leader in charge of the entrepreneurship training acts as the team leader and the entrepreneurship training office (or the School League Committee)takes responsibility for the specific matters, with other functional departments participating jointly and the work put into practice in the institute layer upon layer. Establish and improve the relevant systems and at the same time improve the hardware and software facilities for the entrepreneurial ability training, providing good conditions for entrepreneurial ability training work.

\section{2) Correctly Position the Concept of College Students'} Entrepreneurial Ability Training

Colleges and universities hold narrow positions on the concepts of entrepreneurial ability training, most of which are positioned as the relatively superficial mass education. As a result, college students' entrepreneurial ability training is limited and the scientific training cannot be realized. To accurately position the concept of college students' entrepreneurial ability, the principle of combining general education and elite education should be adopted. General education gears to the needs of all college students in colleges and universities, imparting the basic knowledge and related concepts of entrepreneurship, which enables the college students to keep energetic in the career, to release their passion and energy, to establish the entrepreneurship and thus to prompt them to carry out the groundbreaking work after graduation. Elite education gears to students with a strong entrepreneurial desire and certain entrepreneurial ability, imparting professional courses related to entrepreneurship and opening all entrepreneurial resources of colleges and universities to those students to foster talents for society.

3) Build the Faculty of Full-Time or Part-Time College Entrepreneurship Education

Whether college students' entrepreneurship training can deploy productively, its security is high-quality entrepreneurship education faculty. Entrepreneurial university teachers should stick to the principle that full-time teachers are the main part and full- time teachers combine with the part-time ones. The full-time team includes leadership in charge of entrepreneurship education, the full-time teachers of entrepreneurship education and entrepreneurial education workers. Colleges and universities should guarantee the quality of entrepreneurship education team from the source, selecting and recruiting those who have relevant professional background and work experience as well as rich innovative consciousness and the dedication to work to enrich the full-time faculty. The part-time team should introduce from society the excellent talents with both academic background and the entrepreneurial experience or excellent entrepreneurship education experts at home and abroad. Improve the practicability of entrepreneurship education by combining closely the theory and practice. At the same time, formulate corresponding training program of entrepreneurship teachers according to the current situation in order to strengthen entrepreneurship education faculty.

4) Construct a Practice Platform for College Students' Entrepreneurial Ability Training

First of all, open up the second classroom. Take the societies in the universities as the carrier, carry out entrepreneurial practice activities, such as setting up entrepreneurial forums, launching simulated entrepreneurship competitions and holding sales elite competitions, etc.. Secondly, the university need to establish entrepreneurial practice base, which is the main battlefield of college students' participation in practical entrepreneurship [3] and the foothold of college students' combination of entrepreneurial theory and practice indeed. Universities should establish all kinds of entrepreneurial bases so that the students' entrepreneurial ability can be trained in the process of practice. An area can be delimited as the entrepreneurial base on campus, with the School League Committee making up the entrepreneurial project management team that will recruits entrepreneurial teams from the entire school. A team can enter entrepreneurial base once it passes through the assessment. In the operation process of the entrepreneurial project, the project management team need to follow up and timely give guidance and entrepreneurial teams need to report the project operation to the teachers regularly. As for the entrepreneurial projects that operate in good condition, students should be encouraged to transfer the model to the society and thus they truly step onto 
the path of self-employment. As for projects in poor operation, the management team should order to make a rectification and evacuate the unsustainable projects from the base. Finally, colleges can open platform for virtual network, virtual business platform can simulate the whole process of enterprise operation, the simulation. Universities can create the online virtual entrepreneurial platform which is able to model and simulate the whole process of enterprise operation. The entrepreneurial base resources are limited, so only a fraction of entrepreneurial teams can enjoy this part of the resources. Other students who have entrepreneurial dreams but do not enter the base can turn to the network platform for virtual role-playing and get familiar with enterprise operation mode, accumulating experience through simulated training experience, which effectively train college students' ability of solving practical problems.

\section{REFERENCES}

[1] Larry c,Farrli.The entrepreneurial age: awakening the spirit fo enterprise in people, companies, and countries[M].New York:Hllworth Press,2001

[2] Yan Qiang, theory of social development[M], Nanjing University Press, 2005.10:15-16

[3] Xu Ailing. Innovation, entrepreneurship and employment are key words of vocational college students' survival and development[J].Research on continuing education, 2011(11):49-51 